\title{
EVALUATION OF THE ORAL HEALTH CONDITIONS OF VOLLEYBALL ATHLETES
}

\author{
AVALIAÇÃO DAS CONDIÇÕES DA SAÚDE BUCAL DOS ATLETAS DE VOLEIBOL
}

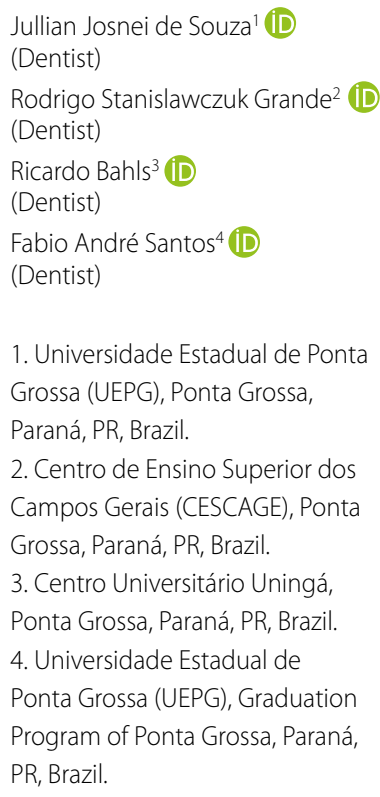

\section{Correspondence:}

Jullian Josnei de Souza Universidade Estadual de Ponta Grossa (UEPG) - Campus de Uvaranas. Av. General Carlos Cavalcanti, 4748 Ponta Grossa, Paraná, PR, Brazil. 84.030-900. jukajs@hotmail.com

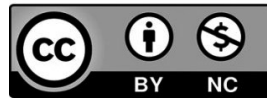

\begin{abstract}
Introduction: Dental care can improve athletes' performance, promoting oral health and preventing changes that could disrupt their sports routine. Objective:To evaluate the dental conditions, habits, and oral health care of volleyball athletes, and their knowledge of the importance of oral health in sports performance. Methods: Sixty-four male athletes participated in the study: 40 from the basic categories ( $16 \pm 3$ years) and 24 professionals ( $25 \pm 5$ years). For the assessment of oral conditions, changes in the temporomandibular joint, history of facial and dental trauma, and the presence of malocclusions and orthodontic treatment were verified. Hygiene was measured by the visible plaque index. To determine the athletes' oral hygiene, they were asked how many times per day they brushed their teeth, flossed their teeth, or used oral mouthwash. Finally, we evaluated the athletes' opinions concerning the importance of oral health and sports performance. Data analysis was performed using the Mann-Whitney and Fisher's Exact tests, with a significance level of 5\%. Results: For most of the parameters evaluated, similar results were found between professional and baseline athletes $(p>0.05)$. However, for the parameters "flossing" ( $p=0.0027)$ and "facial/dental trauma" $(p=0.0444)$, significant differences were observed $(p<0.05)$ between the categories of athletes. Conclusion: We conclude that professional athletes are more prone to facial/dental trauma, and that the presence of a dental surgeon to assist the team improves athletes' overall oral health. Level of evidence Il; Retrospective study.
\end{abstract}

Keywords: Oral health; Athletes; Volleyball; Sports medicine.

\section{RESUMO}

Introdução: A atenção odontológica pode melhorar o rendimento dos atletas, promovendo a saúde bucal e prevenindo que quaisquer alterações atrapalhem a sua rotina de esporte. Objetivo: O presente estudo teve como objetivo avaliar as condições odontológicas, os hábitos, cuidados com a saúde bucal e o conhecimento dos atletas de voleibol sobre a importância da saúde bucal na performance. Métodos: Participaram da pesquisa 64 atletas do sexo masculino, sendo 40 da categoria de base (16 \pm 3 anos) e 24 profissionais ( $25 \pm 5$ anos). Para a avaliação das condições bucais foram verificadas as alterações na articulação temporomandibular, histórico de trauma facial e dental, presença de maloclusões e tratamento ortodôntico. A condição de higiene foi mensurada através do índice de placa visivel. Ainda com o objetivo de caracterizar as condições de higiene bucal, os atletas foram questionados quanto ao número de escovações diárias, uso do fio dental e enxaguatórios bucais. Por fim, avaliamos a opinião dos atletas sobre a importância da saúde bucal com a performance esportiva. A análise dos dados foi realizada com os testes de Mann-Whitney e Exato de Fisher com nivel de significância de 5\%. Resultados: Constatou-se que para a maioria dos parâmetros avaliados os resultados eram semelhantes entre os atletas profissionais e os da categoria de base ( $p>0,05)$. Porém, para os parâmetros "uso do fio dental" ( $p=0,0027)$ e "trauma facial/dental" ( $p=0,0444)$, observaram-se diferenças significativas $(p<0,05)$ entre as categorias. Conclusão: Os atletas profissionais estão mais propensos a traumatismos faciais/dentais, sendo assim, a presença de um cirurgião-dentista dentro da equipe melhora as condições gerais de saúde bucal dos atletas. Nível de evidência ll; Estudo retrospectivo.

\section{Descritores: Saúde bucal; Atletas; Voleibol; Medicina esportiva.}

\section{RESUMEN}

Introducción: La atención odontológica puede mejorar el rendimiento de los atletas, promoviendo la salud bucal y previniendo cualesquiera alteraciones que interrumpan su rutina deportiva. Objetivo: El presente estudio tuvo como objetivo evaluar las condiciones odontológicas, los hábitos, cuidados con la salud bucal y el conocimiento de los atletas de vóleibol sobre la importancia de la salud bucal en el desempeño. Métodos: Participaron en la encuesta 64 atletas del sexo masculino, siendo 40 de las categorías de base (16 \pm 3 años) y 24 profesionales ( $25 \pm 5$ años). Para la evaluación de las condiciones bucales se verificaron las alteraciones en la articulación temporomandibular, historial de trauma facial y dental, presencia de maloclusiones y tratamiento ortodóntico. La condición de higiene fue medida a través del índice de placa visible. Aún con el objetivo de caracterizar las condiciones de higiene bucal, los atletas fueron cuestionados sobre el número de cepillados diarios, uso del hilo dental y enjuagues bucales. Por último, evaluamos la opinión de los atletas sobre la importancia de la salud bucal con el desempeño deportivo. El análisis de los datos fue realizado con los tests de Mann-Whitney y Exacto de Fisher con un nivel de significancia de 
5\%. Resultados: Se constató que para la mayoría de los parámetros evaluados los resultados eran semejantes entre los atletas profesionales y los de la categoría de base ( $p>0,05)$. Sin embargo, para los parámetros "uso del hilo dental" $(p=0,0027)$ y "trauma facial/dental" ( $p=0,0444)$, se observaron diferencias significativas $(p<0,05)$ entre las categorías. Conclusión: Los atletas profesionales están más propensos a traumatismos faciales/dentales, siendo así, la presencia de un cirujano dentista dentro del equipo mejora las condiciones generales de salud bucal de los atletas. Nivel de

\section{evidencia Il; Estudio retrospectivo.}

Descriptores: Salud bucal; Atletas; Voleibol; Medicina deportiva.

\section{INTRODUCTION}

Sports dentistry has highlighted the role of dental surgeons in the investigation, prevention, treatment, rehabilitation and understanding of the influence of oral cavity diseases on the performance of professional and amateur athletes, with the purpose of improving sports performance and preventing injuries ${ }^{1-3}$. Dental awareness can improve the performance of athletes, promote oral health, and contribute to better preparation in order to obtain a higher level of performance ${ }^{4-6}$.

Oral diseases can directly affect the overall health of athletes; it is important that athletes maintain good oral health so that they can perform to the best of their capacity ${ }^{4,7,8}$. The presence of inflammatory conditions, orofacial pain, tooth loss, malocclusions, dental erosion (the indiscriminate use of isotonic solutions), mouth breathing, halitosis, temporomandibular disorders (TMDs), and dental trauma are some of the problems that can affect athletes' performance ${ }^{4,9-11}$.

The scope of sports dentistry is broad; it not only encompasses the treatment of injuries in the oral/maxillofacial region and/or making mouth guards, but also includes the prevention and treatment of oral diseases, doping surveillance, monitoring of the use of isotonic solutions, TMDs, respiratory alterations, the impact of stress and anxiety due to training overload, as well as attempts to avoid/minimize such factors interfering with an athlete's performance 3,9,12-15.

Increasing understanding about the importance of oral health in relation to sporting excellence has meant that some aspects of dental care, which were not previously considered, have begun to attract the attention of technical and health teams in order to avoid athletes being absent from training or the impairment of their physical performance. It is important to educate athletes, as well as the general population, of the importance of oral health and the significance of healthy habits in order to maintain overall health. It is the responsibility of dental surgeons to guide athletes, as well as raising awareness for all who practice sports 1,58 .

Studies of elite athletes participating in the Olympic Games (London 2012 and Rio de Janeiro 2016) showed that 32\% of them believed that oral health has an impact on performance, while $27 \%$ reported that oral health affects the quality of life. Difficulties in participating in training due to oral health problems were mentioned by $3 \%$ of the athletes ${ }^{2,5}$ and more than $40 \%$ of them were dissatisfied with their own oral health ${ }^{6}$. In Brazil, surveys of soccer players, basketball players and triathletes indicated that $74 \%, 40 \%$ and $38 \%$ respectively, believed that oral problems interfere with physical performance ${ }^{48}$.

Thus, the aim of this study was to recognize dental conditions, dental habits and oral health care, together with knowledge about the importance of oral health in relation to both amateur and professional athletes. The null hypothesis we tested was that there were no differences between oral conditions, hygiene habits and the importance of oral health in relation to sports performance among youth and professional athletes.

\section{MATERIALS AND METHODS}

This study was approved by the Research Ethics Committee in accordance with ruling №.2,888,375. A total of 64 male athletes were evaluated; they were divided into 24 professional and 40 amateur volleyball players in the city of Ponta Grossa, Paraná, Brazil, who had all played the sport for two years. All the participants signed an informed consent form authorizing their participation in the study.

Although the temporomandibular joint (TMJ) is not considered to be an intraoral structure it can interfere with oral health because it is a fundamental component of the stomatognathic system and has an impact on physical and mental well-being that may reflect the physiological, social and psychological aspects which form the essence of an individual's quality of life $^{11,16}$. For the initial assessment of changes in the TMJ, an anamnesis was conducted which addressed points such as the main complaint, as well as medical and dental history. Questions were also included to evaluate the social, emotional and cognitive behavioral factors that might initiate, maintain or result in patients having these conditions ${ }^{11}$. A clinical evaluation of the TMJ was performed by a previously trained evaluator which included the following: sensitivity to palpation; articular sounds (crackling or crepitation); and quality of movement (amplitude, deviations, locking, dislocation). Consequently, the presence or absence of TMD (temporomandibular dysfunction) was confirmed ${ }^{16}$. The history of facial and dental trauma suffered by the athletes was also verified based on individual medical reports.

This was followed by an evaluation of the presence of malocclusions using Angle's classification. Firstly, the mesiodistal relationships of the dental arches were considered, which was followed by the individual positions of the teeth. These were then divided into the following classes: Class l; Class II division 1, Class II division 2; and Class III'17. The athletes were then grouped as follows: without malocclusion (Class I); and with malocclusion (Classes II and III). Within this context, we verified whether the individuals had already been submitted to some type of orthodontic treatment or not.

The condition of dental hygiene as a risk factor for periodontal disease was measured using the visible plaque index ${ }^{7}$. Each tooth was clinically divided into four surfaces (buccal, lingual, mesial and distal) and was given a score ranging from 0 to 3 as follows: 0 (absence of plaque in the gingival area); 1 (small amount of plaque at the gingival margin when a periodontal probe was placed on the surface of the tooth); 2 (moderate amount of plaque); and 3 (large amount of plaque). The scores were summed and divided according to the number of evaluated teeth and surfaces. The athletes were then asked about the number of times per day that they brushed and flossed their teeth, as well as the number of times they used mouthwash per day, in order to characterize their oral hygiene conditions.

Finally, we verified with the athletes if they believed in a possible causal relationship between oral health conditions and sports performance by asking them the following question: "Do you believe that your oral condition, health or otherwise, can interfere with your performance as an athlete?" This question was asked at two different times, before the oral evaluation and after the instruction of the evaluators. 


\section{Statistical analysis}

We initially performed a descriptive analysis of the data using the relative and absolute values for the evaluated parameters. Comparisons were made between the professional athletes and the youth athletes. For the qualitative, nominal variables (TMD; trauma; malocclusion; orthodontics; daily brushing; use of dental floss, use of mouthwash; and the relationship between oral conditions and sports performance) Fisher's exact test was applied. For the qualitative, ordinal variable (plaque index), the Mann-Whitney test was used. The significance level that was adopted was 5\% (GraphPad Prism version 7.00, GraphPad software, La Jolla, California, USA).

\section{RESULTS}

The average age of the athletes was $16 \pm 3$, and $25 \pm 5$ years for the amateur and professional categories, respectively.

The oral conditions, hygiene habits and the perception of the importance of oral health are presented in Table 1 and Figure 1. The results showed that for most of the evaluated parameters (TMD; malocclusion; orthodontics; plaque index; daily brushing; use of mouthwash; and relationship between oral conditions and sports performance) no significant differences were observed between the professional and amateur athletes ( $p>0.05$ ), so for these variables the null hypothesis was confirmed. However, for the flossing ( $p=0.0027)$ and facial/dental injuries ( $p=0.0444$ ) parameters significant differences were observed between the athletes; consequently, the null hypothesis for these two parameters was rejected.

\section{DISCUSSION}

Our results showed that the vast majority of athletes presented similar dental conditions, both in the professional athletes group and in the amateur group. In general, the amateur athletes presented better oral conditions. This can be explained by the fact that they were still students and were therefore in greater contact with the dental hygiene measures

Table 1. Oral conditions of athletes.

\begin{tabular}{|c|c|c|c|}
\hline \multirow[t]{2}{*}{ Parameters } & \multicolumn{2}{|c|}{ Athletes Category } & \multirow{2}{*}{$\begin{array}{c}P \\
\text { value }^{*}\end{array}$} \\
\hline & $\begin{array}{c}\text { Amateurs } \\
(n=40)\end{array}$ & $\begin{array}{c}\text { Professionals } \\
(n=24)\end{array}$ & \\
\hline \multicolumn{4}{|l|}{ Oral Conditions } \\
\hline TMD (\%) & & & 0.5653(ns) \\
\hline Yes & $9(23)$ & $7(29)$ & \\
\hline No & $31(77)$ & $17(71)$ & \\
\hline Orthodontic Treatment (\%) & & & 0.6091 (ns) \\
\hline Yes & $18(45)$ & $9(37)$ & \\
\hline No & $22(55)$ & $15(63)$ & \\
\hline Malocclusions (\%) & & & $0.3526(\mathrm{~s})$ \\
\hline Yes & $7(17)$ & $7(29)$ & \\
\hline No & $33(83)$ & $17(71)$ & \\
\hline \multicolumn{4}{|l|}{ Oral hygiene habits } \\
\hline Use of dental floss (\%) & & & $0.0027(\mathrm{~s})$ \\
\hline Yes & $8(20)$ & $14(59)$ & \\
\hline No & $32(80)$ & $10(41)$ & \\
\hline Use of mouthwash (\%) & & & 0.7877 (ns) \\
\hline Yes & $12(30)$ & $8(33)$ & \\
\hline No & $28(70)$ & $16(67)$ & \\
\hline \multicolumn{4}{|l|}{ Importance of oral health } \\
\hline $\begin{array}{l}\text { Relationship between oral conditions } \\
\text { and sports performance (\%) }\end{array}$ & & & 0.5434 (ns) \\
\hline Yes & $32(80)$ & $17(71)$ & \\
\hline No & $8(20)$ & $7(29)$ & \\
\hline
\end{tabular}

A

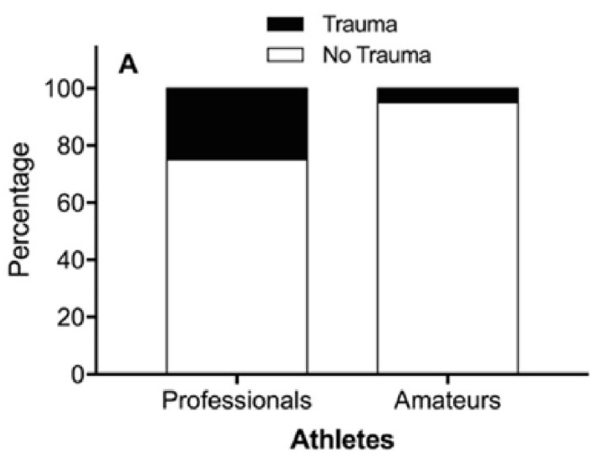

$p=0.0444$, significant (Fisher's exact test)

B

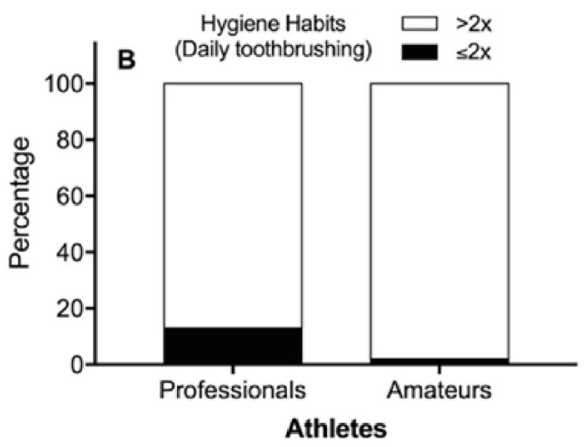

$p=0.1441$, not significant (Fisher's exact test)

C

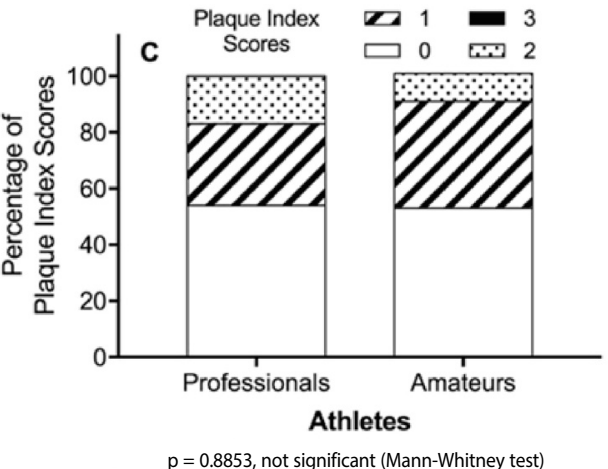

Figure 1. Percentage distribution of parameters regarding oral conditions and oral hygiene in professional and youth athletes. (A) Dental trauma. (B) Hygiene habits (daily toothbrushing). (C) Plaque index.

generally provided by schools. These better oral health conditions may have also been due to the fact they still lived with their parents and that their parents were more likely to emphasize the importance of good health measures ${ }^{18}$. Regarding the professional athletes, it was clear that the stressful routine of training, isotonic intake, and the logistics of travel and competition can influence their routine, thereby often leading them to neglect oral healthcare $9,12-14,19$

The plaque index for both categories of athletes was similar, with average values of $0.62 \pm 0.78$ and $0.57 \pm 0.67$, respectively for the professionals and the amateur category. These results were very similar to those found for competitive and non-competitive swimmers, with average values of $0.61 \pm 0.54$ and $0.75 \pm 0.72$, respectively ${ }^{7}$. However, in our study the amateur athletes brushed and flossed their teeth more frequently than the professionals. In both groups the majority of athletes brushed their teeth more than twice per day; however, most professional 
athletes reported that they did not floss regularly. Previous studies have shown that both elite and amateur athletes brushed their teeth more than twice a day (more than 80\%) 5,8,18. Simple interventions can have a direct impact on oral health, including the use of fluoride dentifrices, the topical application of fluoride, changes in hygiene habits, and the control of diet and consumption of energy and isotonic drinks 3,4,6,8,9,13,18.

Of the total number of athletes in our study (professional and amateur players), 23\% presented some type of malocclusion. Occlusal problems can have a negative impact on sports performance, influencing posture and muscle power in rowers for example ${ }^{15}$. We understand that it would be ideal to reduce the occlusal index as much as possible because the impact of facial orthodontics/orthopedics can increase the level of athletes' performance, taking into consideration improved mouth breathing, chewing, swallowing and digestion, as well as reduced aesthetic problems and the occurrence of dental trauma ${ }^{17}$. Breathing through the mouth implies a change in the quality and volume of air reaching the lungs, thus reducing the effectiveness of the respiratory process, which may hinder the volume of an athlete's breathing during sports activities and may therefore have a negative impact on their performance 10,17. Athletes who breathe through their mouth while performing their physical activities have reduced aerobic endurance, causing a negative impact of up to $20 \%$ on their performance 4 .

Temporomandibular disorders (TMDs) are characterized by craniofacial pain, which affects the joint itself, masticatory muscles, and the head and neck region. TMDs can present main symptoms such as facial pain, discomfort in the ears, headache, and mandibular discomfort or disfunction ${ }^{11}$. In our study, $25 \%$ of the athletes had some type of TMD. The literature reports that $40-75 \%$ of adults have at least one sign of a TMD, but $50 \%$ of these are asymptomatic ${ }^{16}$. Athletes with TMD may have impaired performance because this condition, in addition to the numerous symptoms already mentioned, may also increase the risk of a person becoming a mouth breather $3,10,15$. Another important factor is that professional athletes are constantly exposed to stress and demands which may favor the onset of TMDs. There is a relationship between TMDs and psychopathological changes such as anxiety, depression and stress 10,11,15,16.

Our study focused on volleyball players, and the amateur players reported few cases of facial/dental injuries (5\%); however, in the case of the professional players this figure rose to $25 \%$. Volleyball is not a direct contact sport and a small percentage of facial traumas or dental fractures are to be expected in the sport. For this reason mouth guards are rarely used. Direct contact sports, such as basketball, hockey and rugby, have a higher prevalence of facial/dental injuries, reaching levels of $69 \%, 62 \%$ and 54\%, respectively ${ }^{1,3,4}$.

Regarding sports performance, in our study $71 \%$ of the professional athletes and $80 \%$ of the youth players stated that oral health can influence performance. The technical team of the athletes participating in our study included a dental surgeon who, apart from performing standard dental treatment, was also responsible for recommending oral health prevention and promotion oral health actions for the athletes. This role is increasing in line with the promotion of oral health measures and policies which athletes, especially professionals, are now having greater access to. Studies involving professionals from different modalities have shown a wide variation in relation to this perception, with reports that $5-74 \%$ of professionals consider that oral problems can impair training and negatively interfere with sports performance ${ }^{1,3,4,6,8}$.

\section{CONCLUSION}

The athletes presented good dental conditions, oral hygiene habits, and knowledge about the importance of oral health in relation to sports performance. The professional athletes were more prone to facial/ dental injuries. The presence of a dental surgeon within a professional team improves general oral health conditions and is important in the preparation process.

\section{ACKNOWLEDGEMENTS}

The authors thank all the support of Grupo OdontoPonta CNPJ: 03785927/0001-72, which provided support of physical and material structure for the realization of this work.

This study was financed in part by the Coordenação de Aperfeiçoamento de Pessoal de Nível Superior - Brasil (CAPES) - Finance Code 001.

All authors declare no potential conflict of interest related to this article

AUTHORS' CONTRIBUTIONS: Each author made significant individual contributions to this manuscript. JJS: conception or design of the work, clinical assessment of the athletes, analysis or interpretation of the data for the work, statistical analysis and writing; RSG: conception or design of the work, clinical assessment of the athletes. RB: recruitment of the volunteer athletes and clinical assessment of the athletes. FAS: analysis or interpretation of the data, critical review of its intellectual content, final approval of the version of the manuscript to be published. All the authors reviewed and approved the final version of the manuscript

\section{REFERENCES}

1. Ashley P, Di lorio A, Cole E, Tanday A, Needleman I. Oral health of elite athletes and association with performance: a systematic review. Br J Sports Med. 2015;49(1):14-9.

2. Gallagher J, Ashley P, Petrie A, Needleman I. Oral health and performance impacts in elite and professional athletes. Community Dent Oral Epidemiol. 2018;46(6):563-8.

3. Needleman I, Ashley P, Fine P, Haddad F, Loosemore M, de Medici A, et al. Oral health and elite sport performance. Br J Sports Med. 2015;49(1):3-6.

4. Alves DC, dos Anjos VD, Giovannini JF, Lima RP, Mendonça SM. Dentistry in sport: knowledge and habits of soccer and basketball athletes regarding oral health. Rev Bras Med Esport. 2017;23(5):407-11.

5. Kragt L, Moen MH, van Den Hoogenband CR, Wolvius EB. Oral health among Dutch elite athletes prior to Rio 2016. Phys Sports Med. 2019;47(2):182-8.

6. Needleman I, Ashley P, Petrie A, Fortune F, Turner W, Jones J, et al. Oral health and impact on performance of athletes participating in the London 2012 Olympic Games: a cross-sectional study. Br J Sports Med. 2013;47(16):1054-8.

7. D'Ercole S, Tieri M, Martinelli D, Tripodi D. The effect of swimming on oral health status: competitive versus non-competitive athletes. J Appl Oral Sci. 2016;24(2):107-13.

8. Nascimento BL, Zen IR, Demenech LS, Mazzetto NC, Spada PC. Knowledge of triathlon athletes about the relationship between oral health and performance. RSBO (Impr). 2015;12(4):352-5.

9. Antunes LS, Veiga L, Nery VS, Nery CC, Antunes LA. Sports drink consumption and dental erosion among amateur runners. J Oral Sci. 2017;59(4):639-43.

10. Boas AP, Marson FA, Ribeiro MA, Sakano E, Conti PB, Toro AD, et al. Walk test and school performance in mouth-breathing children. Braz J Otorhinolaryngol. 2013;79(2):212-8.
11. Durham J, Newton-John TR, Zakrzewska JM. Temporomandibular disorders. BMJ. 2015;350:h1154.

12. Clemente FM, Mendes B, Palao JM, Silverio A, Carriço S, Calvete F, et al. Seasonal player wellness and its longitudinal association with internal training load: study in elite volleyball. J Sports Med Phys Fitness. 2019;59(3):345-51.

13. Del Coso J, Pérez-López A, Abian-Vicen J, Salinero JJ, Lara B, Valadés D. Enhancing physical performance in male volleyball players with a caffeine-containing energy drink. Int J Sports Physiol Perform. 2014;9(6):1013-8

14. Horta TA, Bara Filho MG, Coimbra DR, Miranda R, Werneck FZ. Training load, physical performance, biochemical markers, and psychological stress during a short preparatory period in brazilian elite male volleyball players. J Strength Cond Res. 2017.

15. Leroux E, Leroux S, Maton F, Ravalec X, Sorel O. Influence of dental occlusion on the athletic performance of young elite rowers: a pilot study. Clinics (Sao Paulo). 2018;73:e453.

16. Scrivani SJ, Keith DA, Kaban LB. Temporomandibular disorders. N Engl J Med. 2008;359(25):2693-705.

17. Souza LA, Elmadjian TR, Brito e Dias R, Coto NP. Prevalence of malocclusions in the 13-20-year-old categories of football athletes. Braz Oral Res. 2011;25(1):19-22.

18. Anttonen V, Kemppainen A, Niinimaa A, Pesonen P, Tjaderhane L, Jaana L. Dietary and oral hygiene habits of active athletes and adolescents attending ordinary junior high schools. Int J Paediatr Dent. 2014;24(5):358-66.

19. Mendes B, Palao JM, Silverio A, Owen A, Carriço S, Calvete F, et al. Daily and weekly training load and wellness status in preparatory, regular and congested weeks: a season-long study in elite volleyball players. Res Sports Med. 2018;26(4):462-73. 